PNL-2383

UC-41

\title{
Radionuclide Concentrations \\ in Selected Foodstuffs and \\ Wildlife from the Hanford \\ Environs, 1971-1975
}

November 1977

Prepared for the

U.S. Department of Energy

under Contract EY-76-C-06-1830

\section{Battelle}

Pacific Northwest Laboratories 


\title{
NOTICE
}

This report was prepared as an account of work sponsored by the United States Covernment. Neither the United States nor the Department of Energy, nor any of their employees, nor any of their contractors, subcontractors, or their employees, makes any warranty, express or implied, or assumes any legal liability or responsibility for the accuracy, completeness or usefulness of any information, apparatus, product or process disclosed, or represents that its use would not infringe privately owned rights.

The views, opinions and conclusions contained in this report are those of the contractor and do not necessarily represent those of the United States Covernment or the United States Department of Energy.

\author{
PACIFIC NORTHWEST LABDRATOR' \\ noerated by \\ B.ATTELLE \\ for the \\ UNITED STATES DEPARTMENT OF ENERCY \\ Under Contrac: EY-76-C-06-1630
}

\author{
Printed in the United States of America \\ Available from \\ National Technical Intormation Service \\ United States Department of Commerce \\ 5205 Port Royal Road \\ Springfield, Virginia 22751
}

Price: Printed Copy $\$$ : : Microfiche $\$ 3.00$

$\begin{array}{cc}\text {-Pages } & \begin{array}{c}\text { Nris } \\ \text { Selling Price }\end{array} \\ 201-025 & 54.50 \\ 026-0.50 & 55.100 \\ 051-075 & 55.50 \\ 076-100 & 56.00 \\ 101-125 & 56.50 \\ 126-150 & 57.00 \\ 151-175 & 57.75 \\ 176-200 & 56.50 \\ 201-225 & 56.75 \\ 226-250 & 59.00 \\ 251-275 & 510.90 \\ 276-300 & 510.25\end{array}$


RADIONUCLIDE CONCENTRATIONS IN SELECTED

FOODSTUFFS AND WILDLIFE FROM THE HANFORD

ENVIRONS, 1971-1975

by
J. J. Fix
S. C. Leete ${ }^{(a)}$
P. E. Bramson

November 1977

(a) This author's work was supported by the U. S. Energy Research and Development Administration Contract No. E(45-1)-2225, during a Northwest College and University Association for Science Appointment.

BATTELLE

Pacific Northwest Laboratories

Richland, Washington 99352 
CONTENTS

LIST OF FIGURES . . . . . . . . . . . . . . . . . . . . iv

LIST OF TABLES. . . . . . . . . . . . . . . . . $\quad v$

INTRODUCTION. . . . . . . . . . . . . . . . I

SUMMARY . . . . . . . . . . . . . . . . . . 2

FOODSTUFF DATA ANALYSIS ................. 5

MILK . . . . . . . . . . . . . . . . 6

BEEF ...................... 10

CHICKEN AND EGGS . . . . . . . . . . . . . . 12

GREEN LEAFY VEGETABLES ................. 15

WILDLIFE DATA ANALYSIS. . . . . . . . . . . . . . . 18

WHITEFISH. . . . . . . . . . . . . . 18

DEER ...................... 22

OYSTERS. . . . . . . . . . . . . . . . 24

ACKNOWLEDGMENTS ..................... . . . . . . 27

REFERENCES. . . . . . . . . . . . . . . 28 


\section{FIGURES}

1. Foodstuff Sampling Locations from Local Farms in the Hanford Environs, 1971-1975. Sampies Were Also Obtained from Retai1

Outlets.................... 5

2. Probability Plot of Milk Samples Obtained from Commercial

Sources Representing Watersheds East and West of the

Cascades....................... 7

3. Probability Plot of $90 \mathrm{Sr}$ Concentrations in Milk from Hanford

Vicinity Farms ..................... 8

4. Observed $65 \mathrm{Zn}$ and $131 \mathrm{I}$ Concentrations in Milk Obtained from Hanford Vicinity Farms . . . . . . . . . . . . . . 9

5. Probability Plot of $40 \mathrm{~K},{ }^{90} \mathrm{Sr}$ and $137 \mathrm{Cs}$ Activity in Beef Samples...................... . . 12

6. Probability Plot of Naturally-0ccurring $40 \mathrm{~K}$ Concentrations in Chicken and Egg Samples............... 15

7. Probability Plot of ${ }^{40} \mathrm{~K}$ and $90 \mathrm{Sr}$ Concentrations in Leafy Green Vegetables.................. . 17

8. Deer and Whitefish Sample Collection Locations from

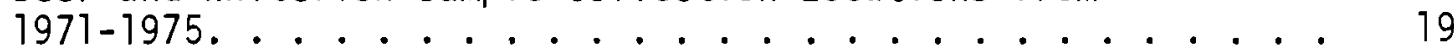

9. Potassium-40 and $65 \mathrm{Zn}$ Levels in Whitefish obtained from 1971 Through 1975. . ................. 21

10. Data Collected from 1971 Through 1975 Showing the Levels of ${ }^{40} \mathrm{~K},{ }^{90} \mathrm{Sr}$ and ${ }^{137} \mathrm{Cs}$ in Whitefish ............. 22

11. Levels of ${ }^{40} \mathrm{~K}$ and ${ }^{137} \mathrm{Cs}$ Shown in Deer Muscle Samples Collected Over the Period, 1971 Through 1975............ 23

12. Plot of ${ }^{40} \mathrm{~K}$ and ${ }^{65} \mathrm{Zn}$ Concentrations in Willapa Bay Oysters.. 


\section{TABLES}

1. Radiochemical Analyses of Milk Samples . . . . . . . . 6

2. Radiochemical Analyses of Beef Samples Obtained from Local Farms and the Riverview Farming Area . . . . . . . .

3. Radiochemical Analyses of Chicken Muscle Obtained from Local Farms and Commercial Stores . . . . . . . . 13

4. Radiochemical Analyses of Chicken Eggs Obtained from Local Farms and Commercial Stores . . . . . . . . . 14

5. Radiochemical Analyses of Green Leafy Vegetables Obtained from Local Farms and Commercial Stores. . . . . . . 16

6. Radiochemical Analysis of Whitefish. . . . . . . . . . 20

7. Radiochemical Analyses of Deer Muscle Samples. . . . . . . 23

8. Radionuclides Observed in Willapa Oysters. . . . . . . 25 


\section{INTRODUCTION}

Foodstuffs such as milk, meat, chicken, eggs and leafy vegetables have been routinely collected from the Hanford environs to measure the presence of radionuclides potentially attributable to Hanford operations. Similarly, samples of fish, deer, and game birds from the Hanford environs, as well as oysters from Willapa Bay, have been analyzed. The data obtained from 1971 through 1975 are included in this document with the exception of game birds. The game bird data have been published in a separate report (BNWL-2089). (1)

The results for the period 1971-1975 presented in this report provide an assessment of the impact from Hanford operations for these years in particular. However, they also serve to assess the significance of any cumulative buildup of the radionuclides observed during the 25 years of Hanford operations previous to this time period.

Whenever possible, the data were analyzed for apparent differences between locations potentially affected by Hanford operations and those unlikely to be affected. In all cases, differences from year to year which may be related to changes in Hanford operations were examined. In some cases, specific radionuclides were observed that were directly related to releases from the once-through cooling production reactors, the last of which was deactivated during January 1971.

A11 of the data for each year is presented in tabular form. Average values and range of values observed are included. Sequential time and/or log-normal probability plots of the data are provided whenever sufficient data are greater than the detection leve1. Dose estimates are provided wherever a specific impact is attributable or, in some cases, potentially attributable to Hanford operations. 


\section{SUMMARY}

Selected foodstuffs and wildlife have routinely been collected from the Hanford Site environs to assess the significance of dose from radionuclides which may be attributable to Hanford operations. Oysters from the Washington coast have also been collected and analyzed. Observations have shown that, with few exceptions, the population has not received radionuclide concentrations above natural or fallout levels. Most exceptions resulted from operation of the once-through cooling production reactors, the last of which was deactivated during January 1971. Highlights of all observations follows:

- Milk--Naturally-occurring $40 \mathrm{~K}$ was observed most frequently, and from the available data, a median value of about $1000 \mathrm{pCi} / \ell$ was obtained. A median value of $90 \mathrm{Sr}$ was observed between $2 \mathrm{pCi} / \mathrm{l}$ and $4 \mathrm{pCi} / 2$ and attributed to fallout. Iodine-131 was observed occasionally with the higher concentrations generally following an atmospheric nuclear detonation by the Peoples Republic of China. The appearance of $65 \mathrm{Zn}$ was attributed to past operation of the once-through cooiing production reactors. During 1971 , the 50-year whole body dose commitment potentially received by a person consuming 365 liters of milk containing $100 \mathrm{pCi} / \mathrm{l}$ of ${ }^{6} 5 \mathrm{Zn}$ was $0.1 \mathrm{mrem}$. (See pages 6-9.)

- Beef--Potassium-40 was observed in the highest concentrations and a median value of $2 \mathrm{pCi} / \mathrm{g}$ was observed. Strontium-90 and ${ }^{137} \mathrm{Cs}$ were observed occasionally, and attributed to worldwide fallout. (See pages 10-12.)

- Chickens and Eggs--Potassium-40 was the only radionuclide observed consistently. A median value for chicken and eggs of $1.8 \mathrm{pCi} / \mathrm{g}$ and $0.9 \mathrm{pCi} / \mathrm{g}$, respectively, was observed. (See pages 12-15.)

- Green Leafy Vegetables--A median value for ${ }^{40} \mathrm{~K}$ of $3 \mathrm{pCi} / \mathrm{g}$ was observed in samples of spinach, leaf lettuce, turnip greens and mustard greens. Strontium-90, observed in most samples, was attributed to fallout and showed a median concentration of 
$0.01 \mathrm{pCi} / \mathrm{g}$. Only one analysis of ${ }^{137} \mathrm{Cs}$ was above the detection level. (See pages 15-17.)

- Whitefish--Potassium-40 from natural causes as well as $90 \mathrm{Sr}$ and ${ }^{137} \mathrm{Cs}$ attributed to fallout were observed. Median concentrations for ${ }^{40} \mathrm{~K}$ and ${ }^{137} \mathrm{Cs}$ were $3.2 \mathrm{pCi} / \mathrm{g}$ and $0.17 \mathrm{pCi} / \mathrm{g}$, respectively. The majority of whitefish analyzed for ${ }^{90} \mathrm{Sr}$ yielded less than detectible results. However, a median concentration between 0.001 and $0.01 \mathrm{pCi} / \mathrm{g}$ is estimated. Phosphorus -32 and $65 \mathrm{Zn}$ were observed and attributed to operation of the once-through cooling reactors. Following deactivation of the last of these reactors during January 1971, 32p with a half-1ife of 14 days showed rapid decline. Zinc-65 concentrations gradually declined and were less than detectible by 1973. Assuming that during the year 1971, a local person consumed $18 \mathrm{~kg}$ of fish containing the average quantity of ${ }^{32} \mathrm{p}$ and ${ }^{65} \mathrm{Zn}$ observed that year, he would have incurred a 50-year whole body dose commitment of $0.4 \mathrm{mrem}$ and $0.3 \mathrm{mrem}$, respectively. (See pages 18-22.)

- Deer-Potassium-40 was observed most frequently and in the greatest concentrations with a median observed concentration of about $2.5 \mathrm{pCi} / \mathrm{g}$. Cesium-137 was detected in a few deer samples, but it is difficult to determine whether Hanford operations have contributed to those levels. Strontium-90 was less than detectible in all but one sample. (See pages 22-24.)

- Willapa Bay Oysters--Potassium-40 was detected in a11 samples and a median concentration of about $2 \mathrm{pCi} / \mathrm{g}$ was observed. For ${ }^{137} \mathrm{Cs}, 8$ of the 35 samples analyzed yielded slightly positive results which could be attributed to fallout. During the 5-year period, a dramatic decrease in ${ }^{65} \mathrm{Zn}$ concentrations in oysters was observed with an approximate 100-fold decrease between 1971 and 1975. For 1971, dose calculations for a person consuming $9 \mathrm{~kg}$ of oyster meat containing the average concentration of $65 \mathrm{Zn}$ observed $(4.6 \mathrm{pCi} / \mathrm{g})$ result in a potential 50 -year dose commitment of $0.3 \mathrm{mrem}$ to the whole body and $0.2 \mathrm{mrem}$ to the bone. (See pages 24-26.) 
The preceeding dose estimates may be compared to the approximate $100 \mathrm{mrem} / \mathrm{yr}$ received from naturally-occurring radionuclides or a dose accumulation of 5000 mrem $(50 \times 100)$ during 50 years. Potassium-40 contributes, internally, a whole body dose of about $20 \mathrm{mrem}$ per/year and is included in the 100 mren per/year natural background dose. 


\section{FOODSTUFF DATA ANALYSIS}

To assess the public's potential exposure to radionuclides from Hanford operations, a variety of foodstuffs including milk, meat, chickens, eggs and leafy vegetables have routinely been collected from the Hanford environs. Radionuclides observed included naturally-occurring ${ }^{40} \mathrm{~K}$, as well as the radionuclides ${ }^{90} \mathrm{Sr}$ and ${ }^{137} \mathrm{Cs}$ contributed by worldwide fallout. Radionuclides of Hanford origin would be similar to those from fallout and must necessarily be present in greater levels than the fallout nuclides to be detectible. The following sections examine the data for each foodstuff category separately. Figure 1 shows sampling locations of all foodstuffs.

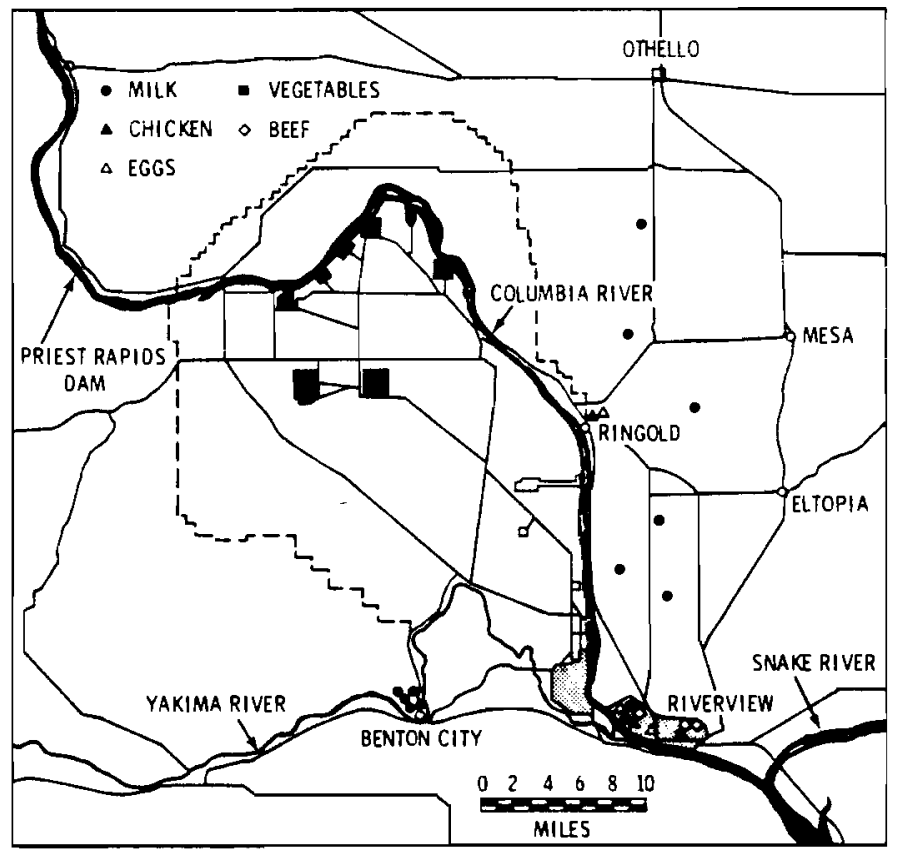

FIGURE 1. Foodstuff Sampling Locations from Local Farms in the Hanford Environs, 1971-1975. Samples were also obtained from Retail Outlets 
MILK

Milk has been sampled from local farms near the Hanford Site, from the Pasco Riverview Area (which is irrigated with Columbia River water) and from two commercial sources (which obtain milk principally from either side of the Cascade mountain range). It has rcutinely been analyzed for gammaemitting radionuclides, $90 \mathrm{Sr}$ and $131 \mathrm{I}$. The results of these analyses are summarized in Table 1.

TABLE 1. Radiochemical Analyses of Milk Samples

Units of $\mathrm{pCi} / \ell$

\begin{tabular}{|c|c|c|c|c|c|c|c|c|c|c|c|c|}
\hline \multirow[b]{2}{*}{ Year } & \multicolumn{4}{|c|}{$40 K$} & \multicolumn{4}{|c|}{$90 \mathrm{Sr}$} & \multicolumn{4}{|c|}{$13^{1} \mathrm{I}$} \\
\hline & $\begin{array}{c}\text { No. of } \\
\text { Samples } \\
\end{array}$ & Max. & Min. & $\underline{A v g}^{(a)}$ & $\begin{array}{l}\text { No. of } \\
\text { Samples }\end{array}$ & Max. & Min. & Avg. & $\begin{array}{l}\text { No. of } \\
\text { Samples } \\
\end{array}$ & Max. & Min. & Avg. \\
\hline & & & & & Loca & arms & & & & & & \\
\hline 1971 & 104 & 1900 & * & $<1140$ & 8 & 3.3 & * & $<2.0$ & 105 & 24.7 & * & $<4.3$ \\
\hline 1972 & 104 & 1600 & * & $<1130$ & 8 & 3.9 & * & $<2.0$ & 103 & 5.4 & * & $<2$. \\
\hline 19973 & 127 & 1400 & - & & 11 & 3.5 & * & $<2.0$ & 127 & 5.4 & * & $<2$. \\
\hline 1974 & 70 & 1300 & * & $<1030$ & 10 & 4.6 & * & 2.7 & 70 & $\star$ & * & $<0$. \\
\hline 1975 & 79 & 1300 & * & $<920$ & 12 & 6.1 & * & $<2.4$ & 79 & 0.4 & * & $<0$. \\
\hline
\end{tabular}

\begin{tabular}{lcccccccccccc}
\multicolumn{7}{c}{ Riverview Farms } \\
1971 & 32 & 1500 & $*$ & $<1120$ & 4 & 3.4 & 0.7 & 2.3 & 21 & 2.3 & $\star$ & $<2.0$ \\
1972 & 26 & 1900 & 740 & 1160 & 4 & 4.4 & 1.1 & 2.7 & 28 & $*$ & $\star$ & $<2.0$ \\
1973 & 26 & 1300 & 700 & 1150 & 4 & 1.5 & 0.7 & 1.1 & 28 & $*$ & $\star$ & $<2.0$ \\
1974 & 26 & 1400 & 710 & 1000 & 4 & 2.6 & $*$ & $<1.8$ & 25 & 3.0 & $\star$ & $<0.5$ \\
1975 & 26 & 1200 & 720 & 830 & 4 & 3.2 & $*$ & $<1.5$ & 26 & 0.4 & $*$ & $<0.4$
\end{tabular}

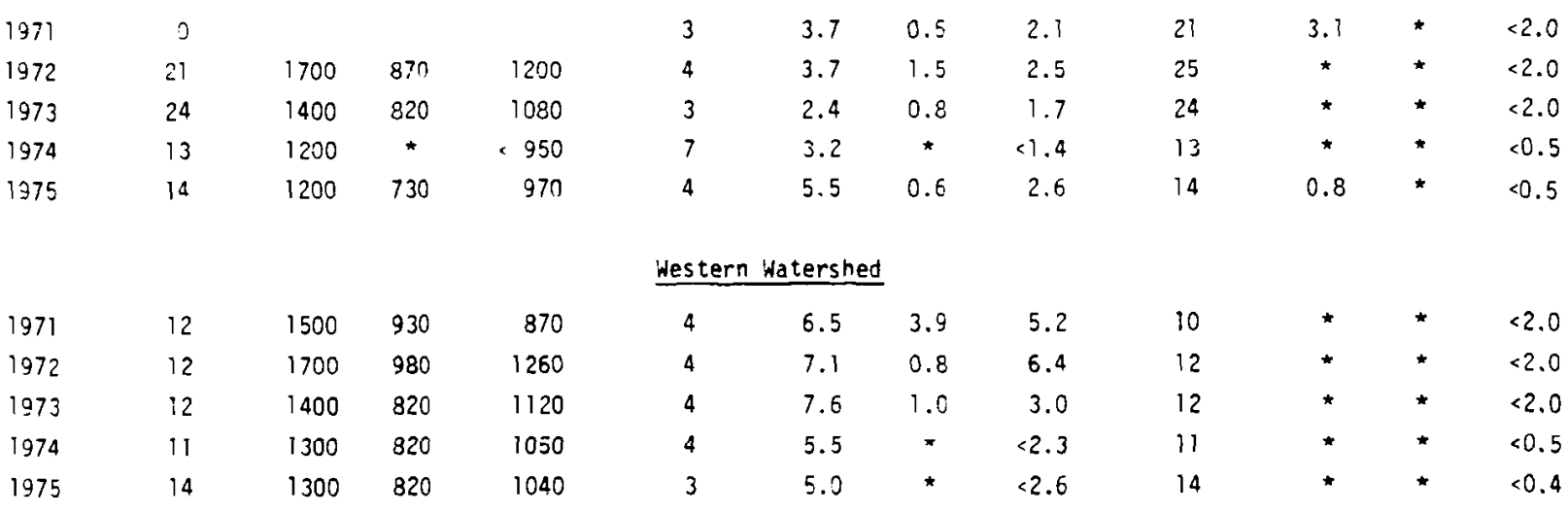

\footnotetext{
"Less than detectible. Approximate detection levels are $40 \mathrm{k}, 2600-, 905 \mathrm{r}, 0.5-$, and ${ }^{131} \mathrm{I}, 2-$ oCi/e during 1971-1973,0.5 oCi/z during 1974, and 0.4 oCi/e during 1975.

(a) Average for data containing less-than values was calculated by assuming all less-than values are equal to the detection level and showing the average as a less-than number.
} 
Before February 1971, routine analysis was made for 32p. Following the January 1971 deactivation of the last once-through cooling reactor, this analysis was stopped ( $32 p-14$ day halfiffe).

Potassium-40 is a naturally-occurring radionuclide and is present in the greatest concentrations. Figure 2 is a log-normal probability plot of the ${ }^{40} \mathrm{~K}$ and ${ }^{90} \mathrm{Sr}$ data for each of the commercial sources of milk, one from each side of the cascades. The figure shows that the $40 \mathrm{~K}$ concentrations are identical. Strontium-90 is present in the environment from worldwide fallout. Figure 2 shows that generally the concentrations in milk are slightly higher west of the cascades than east of the mountains. This can be attributed to the higher rainfall west of the mountains. From figure 2 a median value of approximately $1000 \mathrm{pCi} / \mathrm{e}$ for $40 \mathrm{~K}$ and between 2 and $4 \mathrm{pCi} / \ell$ for ${ }^{90} \mathrm{Sr}$ would be expected.

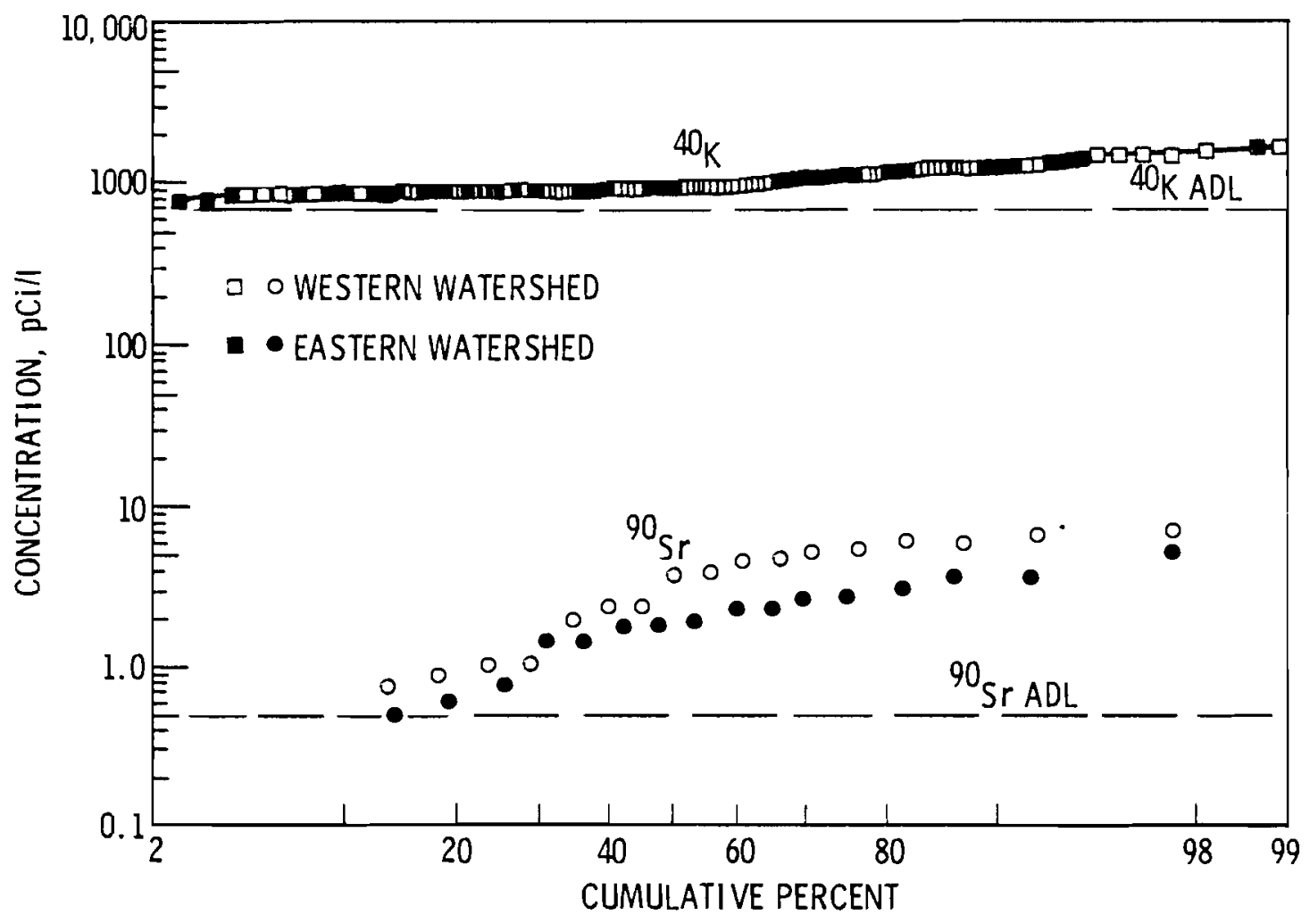

FIGURE 2. Probability Plot of Milk Samples Obtained from Commercial Sources Representing Watersheds East and West of the Cascades 
Figure 3 is a log-normal probability plot of the ${ }^{90} \mathrm{Sr}$ data for local farms, Riverview farms, and commercial sources from the Eastern watershed. Apparently, there is no obvious difference in the concentrations observed in milk from the different sources. This indicates that any Hanford contributions to the levels at local or Riverview farms are indistinguishable from the levels in commercial $\mathrm{mi} 1 \mathrm{k}$ for the region. From Figure $3, \mathrm{a}$ median value of $2 \mathrm{pCi} / l$ of $90 \mathrm{Sr}$ would be expected for all milk produced in the Hanford region.

Iodine-131 concentrations were generally less than detectible, as shown in Table 1, with a few occasional positive measurements. Figure 4 is a sequential plot of the positive 131 I data from 1971 through 1975. Included in Figure 4 is an indication of the occurrence of atmospheric nuclear detonations in the Northern Hemisphere by the Peoples Republic of China, which generally preceded the higher observed concentrations. This was particularly true during the latter part of 1971, the early part of 1972, middle of 1973, and the middle of 1974. The concentrations observed at other times to be slightly above the detection level are attributed to the statistical uncertainty in performing low-level radiochemical analyses.

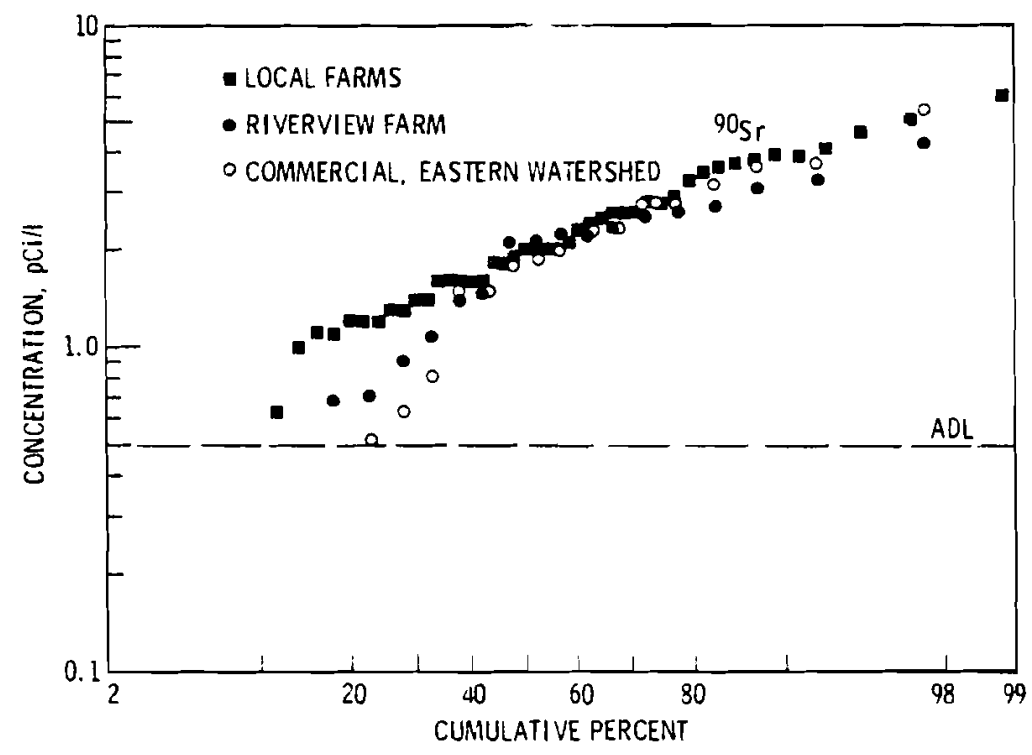

FIGURE 3. Probability Plot of $90 \mathrm{sr}$ Concentrations in Milk from Hanford Vicinity Farms 
Also shown in Figure 4 is the gradual decline in $65 \mathrm{Zn}$ concentrations in milk from the Riverview farms. Zinc- 65 was a prevalent contaminant in the river water used for irrigation and resulted from operation of the once-through cooling production reactors. Following deactivation of the last of these reactors during January 1971 , the ${ }^{6} 5 \mathrm{Zn}$ concentrations gradually became undetectible. Assuming an individual consumed 365 liters ${ }^{(2)}$ of milk during 1971 containing $100 \mathrm{pCi} / 2$ of $65 \mathrm{Zn}$, he or she would incur a 50-year dose commitment of 0.1 mrem to the whole body.

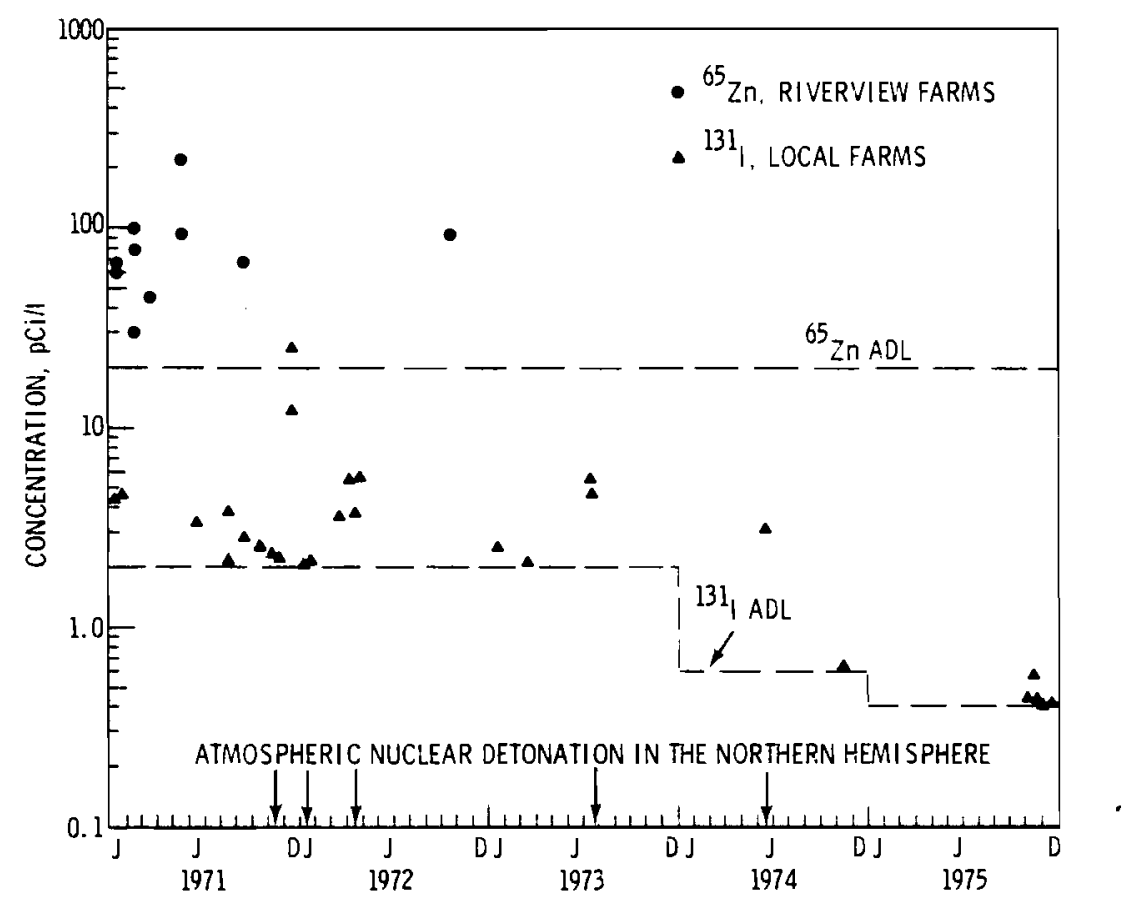

FIGURE 4. Observed ${ }^{65} \mathrm{Zn}$ and ${ }^{131}$ I Concentrations in Milk Obtained from Hanford Vicinity Farms 
Samples were taken of beef grown in Pasco's Riverview area and from a local slaughtering and packing plant. The samples were routinely collected to assess the potential presence of radionuclides attributable to Hanford operations. The packing plant receives cattle from local farms throughout the entire region whereas the Riverview area is directly downstream and downwind of the Hanford Site, as shown in Figure 1.

Table 2 summarizes the maximum, minimum, and average concentration observed for $40 \mathrm{~K},{ }^{90} \mathrm{Sr}$ and ${ }^{137} \mathrm{Cs}$ for samples from $10 \mathrm{Ca} 1$ and Riverview farms for each of the years 1971 through 1975. The tabled data indicates no apparent increase in levels for the Riverview samples. There is an apparent slight decrease in ${ }^{90} \mathrm{Sr}$ and $137 \mathrm{Cs}$ concentrations from 1971 through 1975 that is likely attributable to the gradual decline of atmospheric fallout activity, the major source of $90 \mathrm{Sr}$ and ${ }^{137} \mathrm{Cs}$ in the environment. No other radionuclides were observed except naturally-occurring $40 \mathrm{~K}$.

Figure 5 is a log-normal probability plot of the ${ }^{40} \mathrm{~K},{ }^{90} \mathrm{Sr}$ and ${ }^{137} \mathrm{Cs}$ data greater than the detection level for a 11 of the beef samples. Potassium-40, a natural1y-occurring radionucilide, was observed most frequentiy and in the greatest concentration. From the data in Figure 5, a median concentration for $40 \mathrm{~K}$ in beef of about $2 \mathrm{pCi} / \mathrm{g}$ would be expected. The $90 \mathrm{Sr}$ and $137 \mathrm{Cs}$ shown in Figure 5 are attributed to worldwide fallout. Although the majority of the ${ }^{90} \mathrm{Sr}$ and ${ }^{137} \mathrm{Cs}$ data are less than detectible, one can estimate an expected median value by extrapolation from the plotted data. From Figure 5, the median value for $90 \mathrm{Sr}$ would be between 0.0002 and $0.002 \mathrm{pCi} / \mathrm{g}$; for ${ }^{137} \mathrm{Cs}$ the median would lie between 0.05 and $0.5 \mathrm{pCi} / \mathrm{g}$. The broad range for these estimates is due to the rather large statistical uncertainty associated with the slightly positive data. 
TABLE 2. Radiochemical Analyses of Beef Samples Obtained from Local Farms and the Riverview Farming Area

Units of $\mathrm{pCi} / \mathrm{g}$ (Wet Weight)

Riverview

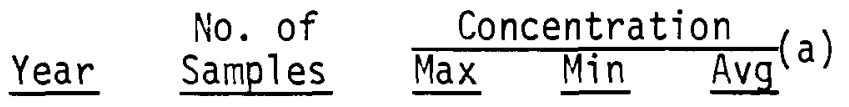

\section{$40 \mathrm{~K}$}

\begin{tabular}{|c|c|c|c|c|c|c|c|c|}
\hline 1971 & 2 & 2.3 & 1.7 & 2.0 & 11 & 2.5 & 1.1 & 1.9 \\
\hline 1972 & 0 & -- & -- & -- & 12 & 2.8 & 1.5 & 2.3 \\
\hline 1973 & 1 & -- & -- & 2.2 & 13 & 2.7 & 1.9 & 2.3 \\
\hline 1974 & 1 & -- & -- & 1.7 & 11 & 2.6 & 1.8 & 2.1 \\
\hline 1975 & 1 & -- & - & 1.9 & 13 & 2.4 & 1.6 & 2.0 \\
\hline \multicolumn{9}{|c|}{$90 \mathrm{Sr}$} \\
\hline 1971 & 0 & -- & -- & -- & 12 & 0.013 & * & $<0.003$ \\
\hline 1972 & 0 & -- & -- & -- & 12 & 0.006 & * & $<0.007$ \\
\hline 1973 & 1 & -- & -- & 0.003 & 13 & 0.005 & * & $<0.002$ \\
\hline 1974 & 1 & -- & -- & $<0.002$ & 11 & * & * & $<0.002$ \\
\hline 1975 & 1 & -- & -- & 0.002 & 13 & 0.007 & * & $<0.003$ \\
\hline \multicolumn{9}{|c|}{$13^{7} \mathrm{Cs}$} \\
\hline 1971 & 2 & * & * & $<0.04$ & 11 & 0.19 & * & $<0.06$ \\
\hline 1972 & 0 & -- & -- & -- & 12 & 0.08 & * & $<0.05$ \\
\hline 1973 & 1 & -- & -- & $<0.04$ & 13 & 0.06 & * & $<0.04$ \\
\hline 1974 & 1 & -- & -- & $<0.04$ & 11 & * & * & $<0.04$ \\
\hline 1975 & 1 & -- & -- & $<0.04$ & 13 & * & * & $<0.04$ \\
\hline
\end{tabular}

No. of Samples Max Min $\underline{\text { Avg }}$

Concentration

$\stackrel{\text { Mnd }}{\longrightarrow}$

Local Farms

\footnotetext{
*Less than detectible. Detection levels are approximately: ${ }^{40} \mathrm{~K}, 0.6-;{ }^{90} \mathrm{Sr}$, $0.002-$; and ${ }^{137} \mathrm{Cs}, 0.04-\mathrm{pCi} / \mathrm{g}$.
}

(a) Average for data containing less-than values was calculated by assuming all less-than values are equal to the detection level and showing the average as a less-than number. 


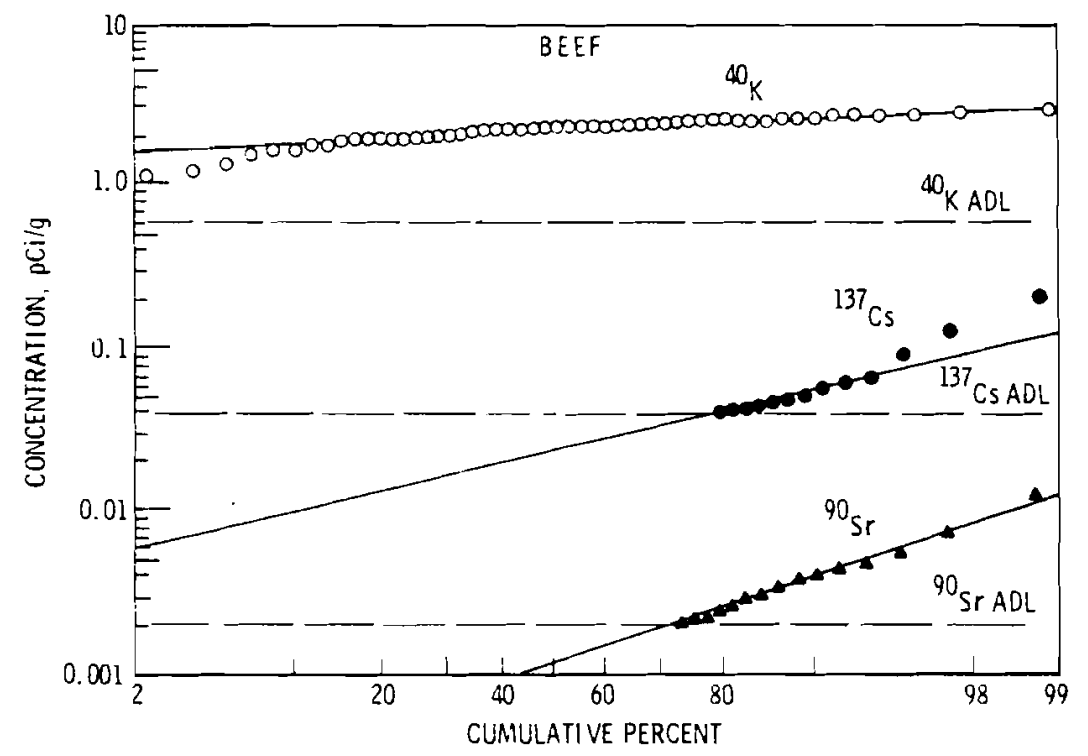

FIGURE 5. Probability Plot of ${ }^{40} \mathrm{~K},{ }^{90} \mathrm{Sr}$ and ${ }^{137} \mathrm{Cs}$ Activity in Beef Samples

\section{CHICKENS AND EGGS}

Each year a few chickens and eggs have been collected from local farms near the Hanford Site and from chain grocery stores for gamma spectral and ${ }^{90} \mathrm{Sr}$ analysis. Generally, the chain grocery stores have carried products which are not locally grown. Any increase in radionliclide concentrations observed for local samples compared to the chain store samples would indicate an apparent impact from Hanford operations.

Tables 3 and 4 summarize the maximum, minimum, and average concentration of ${ }^{40} \mathrm{~K},{ }^{90} \mathrm{Sr}$ and ${ }^{137} \mathrm{Cs}$ in local farm and store samples for each year, 1971 through 1975. The tabled data indicates no distinguishable Hanford impact because the majority of the results, except for ${ }^{40} \mathrm{~K}$, were less than the detection level. Naturally-occurring ${ }^{40} \mathrm{~K}$ was observed in the greatest concentration. Occasionally, ${ }^{90} \mathrm{Sr}$ levels were observed near the detection limit. Cesium-i37 concentrations were less than detectible for all but one egg sample. The single positive measurement was taken in 1972 and was slightly above the detection limit of $0.04 \mathrm{pCi} / 2$.

Figure 6 is a log-normal probability plot of naturally-occurring ${ }^{40} \mathrm{~K}$ in chicken muscle tissue and eggs. From Figure 6 , a median ${ }^{40} \mathrm{~K}$ concentration in chickens and eggs of $1.8 \mathrm{pCi} / \mathrm{g}$ and $0.9 \mathrm{pCi} / \mathrm{g}$, respectively, would be expected. 
TABLE 3. Radiochemical Analyses of Chicken Muscle Obtained from Local Farms and Commercial Stores

Units of $\mathrm{pCi} / \mathrm{g}$ (Wet Weight)

Local Farms

No. of

Year Samples
Conmercial Sources

No. of Samples Max Min $\underline{\text { Avg }}$
1971

1972

1973

1974

1975

1971

1972

1973

1974

1975

$$
\frac{\text { Concentration }}{\text { Max } \quad \text { Min } \quad \text { Avg }}(a)
$$

$$
40 \mathrm{~K}
$$

\section{1}

4

2

4

4

--
2.8
2.2
2.0
2.1

$--$

2.0

2.3

2.0

1.1

1.1

0.003
0.004
$*$
$*$

0.014

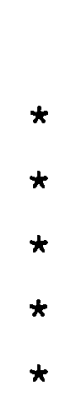
$<0.003$
$<0.003$
$<0.002$
$<0.002$

$<0.006$

0
0
1
2
2

$\begin{array}{lll}-- & -- & -- \\ -- & -- & -- \\ -- & -- & 1.8 \\ 1.6 & 1.5 & 1.6 \\ 1.5 & 1.3 & 1.4\end{array}$

$90 \mathrm{Sr}$

$$
\underline{137 \mathrm{CS}}
$$

1971

1972

1973

1974

1975

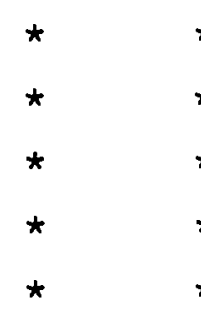

$\begin{array}{ll}* & <0.04 \\ * & <0.04 \\ * & <0.04 \\ * & <0.04 \\ * & <0.04\end{array}$

0
0
1
2
2

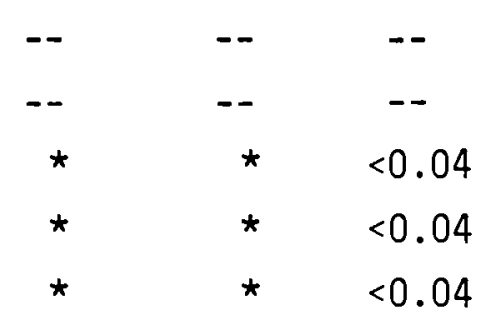

\footnotetext{
*Less than detectible. Detection 1 imits are approximately: ${ }^{40} \mathrm{~K}, 0.6-; 90 \mathrm{Sr}$, $0.002-;$ and ${ }^{137} \mathrm{Cs}, 0.04-\mathrm{pCi} / \mathrm{g}$.

(a) Average for data containing less-than values was calculated by assuming all less-than values are equal to the detection level and showing the average as a less-than number.
} 
TABLE 4. Radiochemical Analyses of Chicken Eggs Obtained

from Local Farms and Commercial Stores

Units of $\mathrm{pci} / \mathrm{g}$ (Wet lleight)

$\underline{\text { Local Farms }}$

Year $\begin{gathered}\text { No. of } \\ \text { Samples }\end{gathered}$

Year Samples
Commercial Sources

No. of

Sarnples Max Min Avg

1971

1972

1973

1974

1975

10

1.6

0.7

1.4

0.7

1.2

0.7

1.1

0.7

$1.1 \quad 0.6$

0.9

13

0.9

1971

1972

1973

1974

1975

1971

1972

1973

1974

1975

$90 \mathrm{sr}$

$\underline{90 \mathrm{sr}}$

$$
0.012
$$

0.003

0.026

0.002

0.007
0.013
$<0.003$
$<0.003$
$<0.002$

$$
\begin{array}{ccc}
0.004 & * & <0.003 \\
0.004 & * & <0.003 \\
* & * & <0.002 \\
& & 137 \mathrm{Cs}
\end{array}
$$

$\begin{array}{ll}* & <0.04 \\ * & <0.04 \\ * & <0.04 \\ * & <0.04 \\ * \quad<0.04\end{array}$

0

0

1

2

2

0.8

$0.95 \quad 1.0$

0.8

0.8 


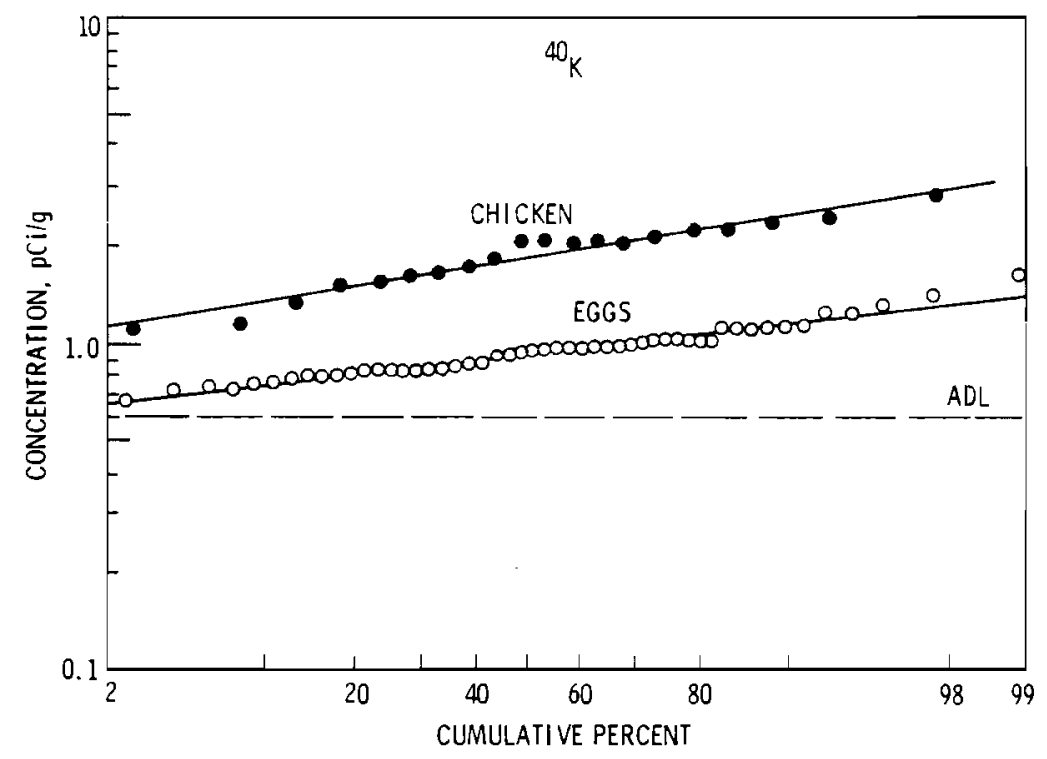

FIGURE 6. Probability Plot of Naturally-Occurring

$40 \mathrm{~K}$ Concentrations in Chicken and Egg

Samples

\section{GREEN LEAFY VEGETABLES}

A few samples of green leafy vegetables such as spinach, leaf lettuce, turnip greens and mustard greens have been collected each year during the summer growing season from local farms and commercial stores for analysis. Local farms sampled always included the Riverview area as shown in Figure 1. Because the commercial produce samples are generally not locally grown, they reflect levels of radionuclides due to fallout.

Table 5 summarizes the maximum, minimum, and average concentration observed for ${ }^{40} \mathrm{~K},{ }^{90} \mathrm{Sr}$ and ${ }^{137} \mathrm{Cs}$ for samples from local farms and grocery stores for each of the years, 1971 through 1975. There is no apparent difference between concentrations for samples from local farms and commercial stores. Naturally-occurring ${ }^{40} \mathrm{~K}$ was observed in the highest concentrations. Strontium-90 measurements were generally positive and the levels observed are attributed to worldwide fallout. Cesium-137 results were less than detectible with one exception for a sample collected from a store in 1971. 
TABLE 5. Radiochemical Analyses of Green Leafy Vegetables Obtained from Local Farms and Commercial Stores

Units of $\mathrm{FCi} / \mathrm{g}$ (Wet Weight)

Local Farms

No. of

Year Samples

$\frac{\text { Concentration }}{\text { Max } \quad \text { Min } \quad \text { Avg }}$

No. of Samples
Commercial Stores $40 \mathrm{~K}$

$\begin{array}{ll}1971 & 3 \\ 1972 & 3 \\ 1973 & 3 \\ 1974 & 5 \\ 1975 & 4\end{array}$

1971

1972

1973

1974

1975

1971

1972

1973

1974

1975

$\begin{array}{ll}3.0 & 2.0 \\ 4.5 & 2.7 \\ 4.9 & 2.0 \\ 3.6 & 1.7 \\ 3.3 & 2.1\end{array}$

2.0

2.7

2.6

3.6

3.0

2.4

2.6

$90 \mathrm{Sr}$

$\begin{array}{llll}-- & -- & -- & 1 \\ -- & -- & 0.030 & 2 \\ -- & -- & 0.005 & 1\end{array}$

$\begin{array}{ll}0.016 & 0.011\end{array}$

0.014

$0.055 \quad 0.025$

0.040

${ }^{137} \mathrm{Cs}$

$\begin{array}{lll}* & * & <0.1 \\ * & * & <0.1 \\ * & * & <0.1 \\ * & * & <0.1 \\ * & * & <0.1\end{array}$



$5.6 \quad 2.4$
Concentration

Max Min Avg

$\begin{array}{ll}4.7 & 0.9\end{array}$

2.9

4.0

$4.0 \quad 2.2$

3.3

$3.2 \quad 1.2$

2.1

$5.1 \quad 2.1$

3.3

1

$\begin{array}{llll}1 & -- & -- & 0.039 \\ 2 & 0.010 & 0.009 & 0.009 \\ 1 & -- & -- & 0.009 \\ 2 & 0.011 & 0.009 & 0.010 \\ 2 & 0.027 & 0.004 & 0.015\end{array}$

*Less than detectible. Detection levels are approximately: $40 \mathrm{~K}, 0.8-;{ }^{90} \mathrm{Sr}$, $0.003-$; and $13^{7} \mathrm{Cs}, 0.1-\mathrm{pCi} / \mathrm{g}$.

(a) Average for data containing less-than values was calculated by assuming all less-than values are equal to the detection level and showing the average as a less-than number. 
Figure 7 is a log-normal probability plot of the ${ }^{40} \mathrm{~K}$ and ${ }^{90} \mathrm{Sr}$ data. Based on the data shown, a median ${ }^{40} \mathrm{~K}$ concentration of about $3 \mathrm{pCi} / \mathrm{g}$ would be expected. The ${ }^{90} \mathrm{Sr}$ plot illustrates the similarity of the local farm and grocery store concentrations. The expected median concentration for ${ }^{90} \mathrm{Sr}$ would be about $0.01 \mathrm{pCi} / \mathrm{g}$.

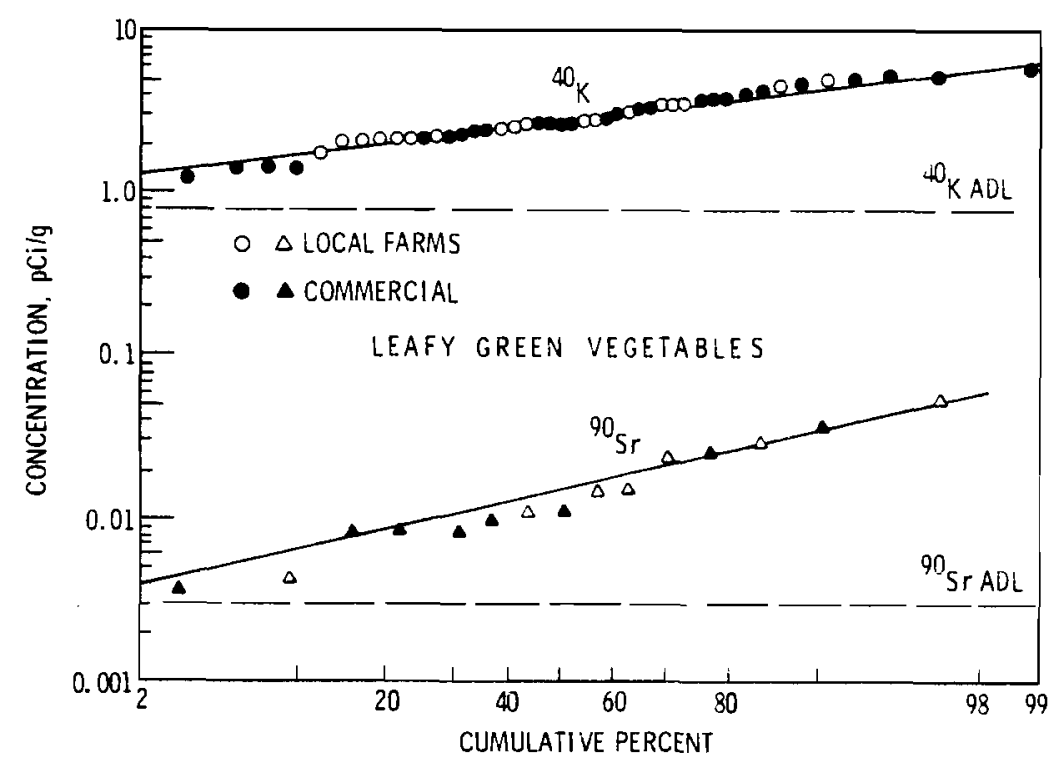

FIGURE 7. Probability Plot of $40 \mathrm{~K}$ and ${ }^{90} \mathrm{Sr}$ Concentrations in Leafy Green Vegetables 


\section{WILDLIFE DATA ANALYYSIS}

A few wildlife species play an important role in assessing the potential dose to people from Hanford operations. The routinely collected species include game birds, fish and deer in the Hanford environs as we 11 as oysters from Willapa Bay along the Pacific Coast. The game bird data for 1971 through 1975 have been evaluated in another report. (1) The species of Columbia River fish collected was whitefish because they are prominent and are caught throughout the year. Generally, deer samples were obtained from road accidents on the Hanford Site. The locations of the samples analyzed are shown in Figure 8. Oysters were obtained from a commercial supplier who farms in Willapa Bay. Radionuclides observed included naturallyoccurring ${ }^{40} \mathrm{~K}$, as we 11 as the worldwide fallout radionuclides, ${ }^{90} \mathrm{Sr}$ and ${ }^{137} \mathrm{Cs}$. Radionuclides of Hanford origin observed included $32 \mathrm{p}$ and $65 \mathrm{Zn}$ from operation of the once-through cooling production reactors and possibly ${ }^{137} \mathrm{Cs}$ at near fallout levels. The following sections examine the data for each wildlife species, separately. Figure 8 shows the location of all fish and deer samples.

\section{WHITEFISH}

Each year for five years, quarterly samples of whitefish from the Columbia River have been routinely collected adjacent to and immediately downstream of the Hanford Site. The samples were taken to assess the concentration of radionuclides potentially attributable to Hanford operations.

Table 6 summarizes the maximum, minimum and average concentrations observed for ${ }^{40} \mathrm{~K},{ }^{32} \mathrm{P},{ }^{65} \mathrm{Zn},{ }^{90} \mathrm{Sr}$ and ${ }^{137} \mathrm{Cs}$ for each of the years 1971 through 1975. The tabled data shows that following the January 1971 shutdown of the last once-through cooling production reactor, the ${ }^{32 p}$ and ${ }^{65} \mathrm{Zn}$ concentrations showed a rapid decrease. Because of the approximate 14 day halflife for $32 p$, this particular analysis was stopped as a routine analyses after March 1971. Occasional analyses were done after this date to insure that continuing reactor operations did not contribute significant quantities of $32 \mathrm{p}$ to the river. Observed levels of ${ }^{90} \mathrm{Sr}$ and ${ }^{137} \mathrm{Cs}$ show no obvious pattern and can be attributed to worldwide fallout. 


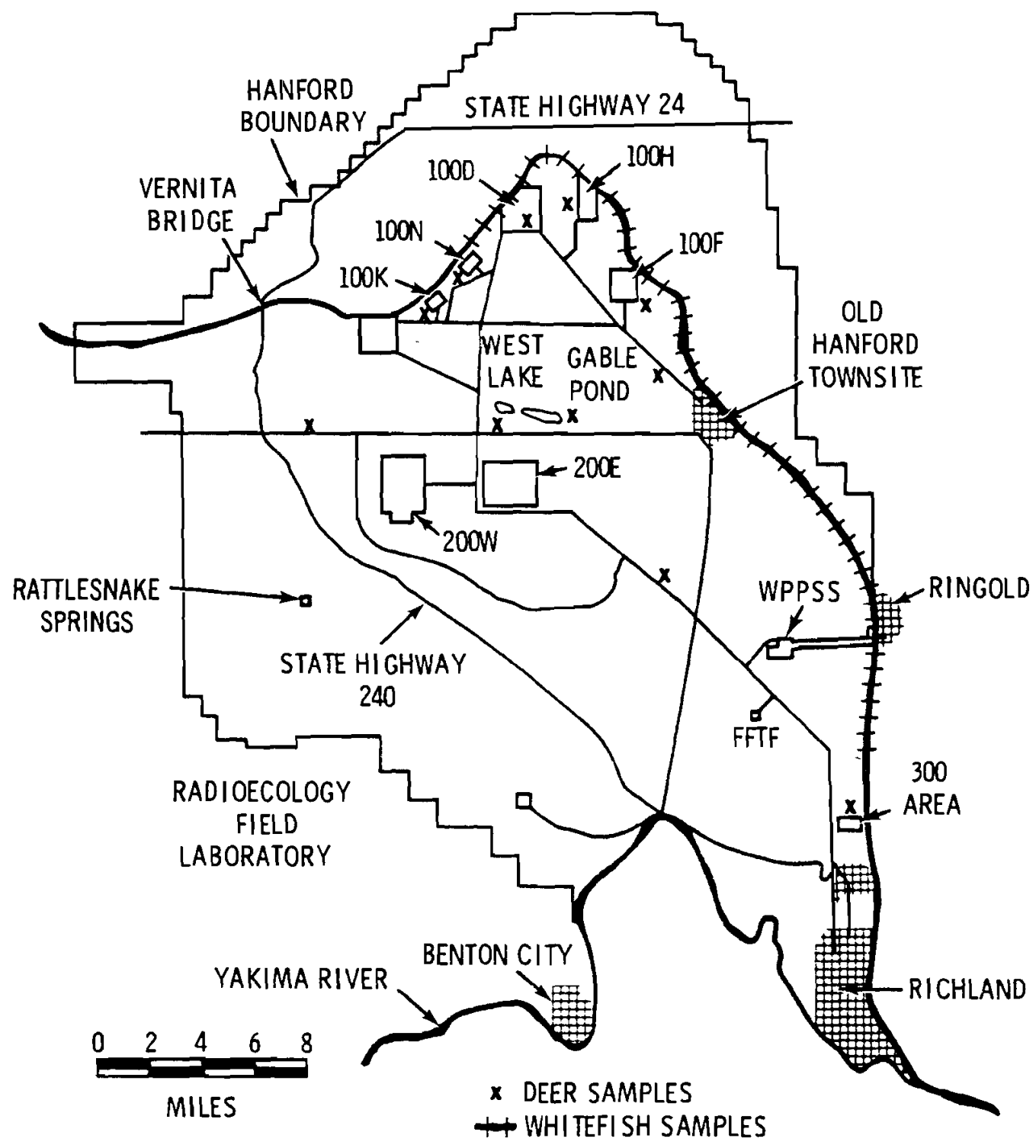

FIGURE 8. Deer and Whitefish Sample Collection Locations from 1971-1975

Figure 9 is a sequential time plot of the ${ }^{40} \mathrm{~K}$ and $65 \mathrm{Zn}$ data obtained from 1971 through 1975. The plotted data illustrate the consistency of the naturally-occurring ${ }^{40} \mathrm{~K}$ concentrations observed throughout the 5 -year period. Figure 9 shows the rapid decline of $65 \mathrm{Zn}$ concentrations in whitefish following shutdown of the last of these reactors. Zinc- 65 had been released to the river by the once-through cooling production reactors. 
TABLE 6. Radiochemical Analysis of Whitefish

Units of $\mathrm{pCi} / \mathrm{g}$ (Wet Weight)

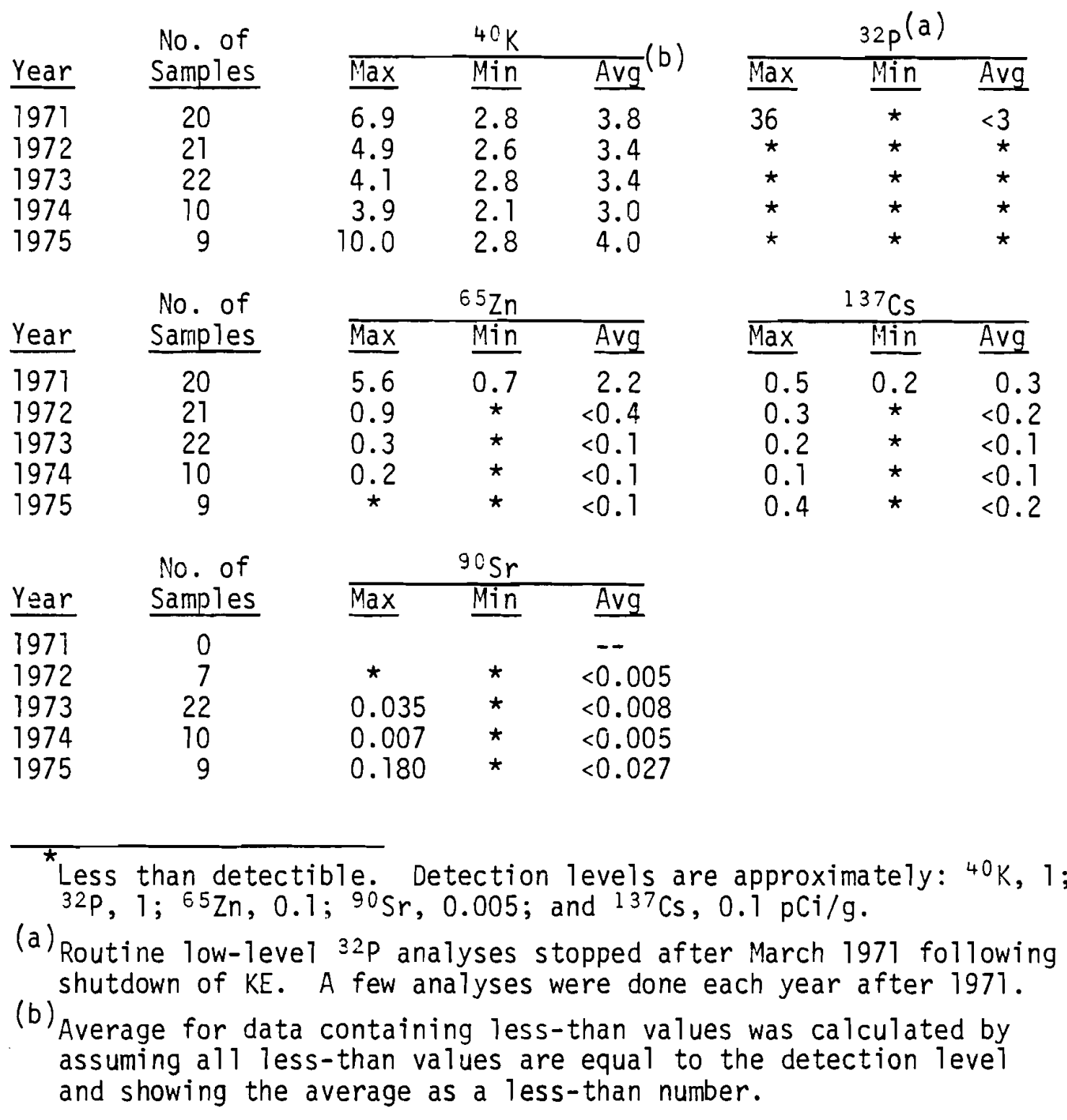




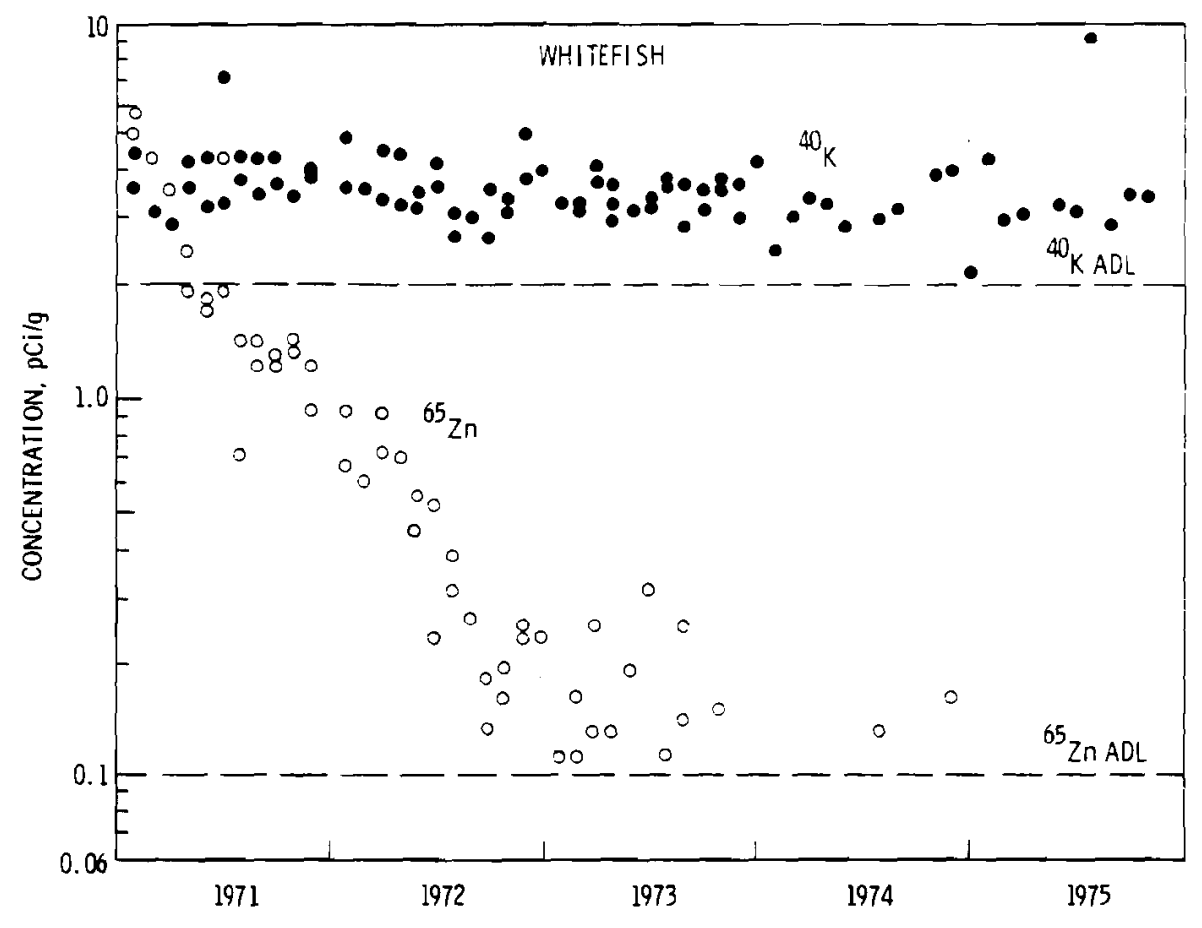

FIGURE 9. Potassium-40 and ${ }^{65} \mathrm{Zn}$ Levels in Whitefish Obtained from 1971 Through 1975

Figure 10 is a log-normal plot of the ${ }^{40} \mathrm{~K},{ }^{90} \mathrm{Sr}$ and ${ }^{137} \mathrm{Cs}$ data. It is apparent that naturally-occurring ${ }^{40} \mathrm{~K}$ is present in the largest concentrations and, from the data in Figure 10, a median value of about $3.2 \mathrm{pCi} / \mathrm{g}$ would be expected. The ${ }^{90} \mathrm{Sr}$ and ${ }^{137} \mathrm{Cs}$ concentrations shown in Figure 10 are attributed to worldwide fallout. Based on the data shown, the expected median concentration of ${ }^{137} \mathrm{Cs}$ would be about $0.17 \mathrm{pCi} / \mathrm{g}$. Strontium-90 in most of the whitefish was less than detectible. However, from the plotted data, a median concentration between 0.001 and $0.01 \mathrm{pCi} / \mathrm{g}$ would be expected.

The dose implication to a person eating whitefish varied greatly from 1971 through 1975 because of the rapid decline in ${ }^{32 p}$ and ${ }^{6}{ }^{5} \mathrm{Zn}$ concentrations following shutdown of the last once-through production reactor during January 1971. Assuming during 1971 an individual consumed $18 \mathrm{~kg}$ of fish which contained the average quantity of ${ }^{32} \mathrm{p}$ and ${ }^{65} \mathrm{Zn}(3 \mathrm{pCi} / \mathrm{g}$ and $2.2 \mathrm{pCi} / \mathrm{g})$ that

\footnotetext{
"Consumption value obtained from ERDA 77-24 for the maximum individual dosage. (Reference 2)
} 


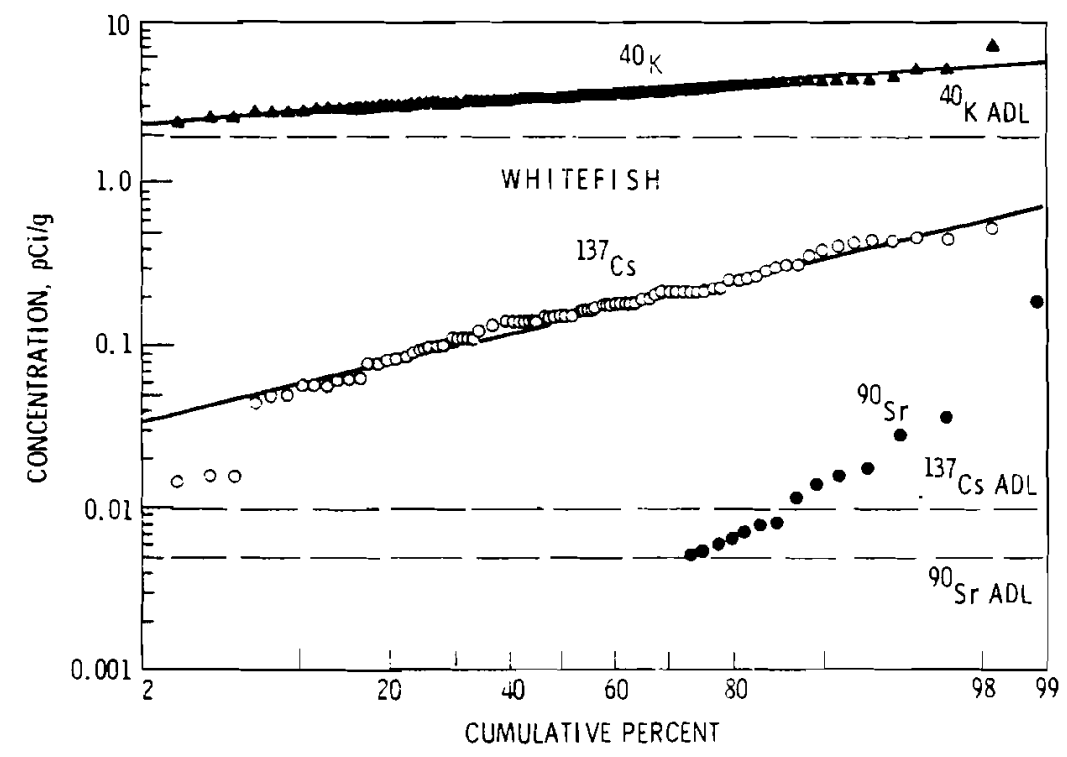

FIGURE 10. Data Collected from 1971 Through 1975

Showing the Levels of $40 \mathrm{~K}, 90 \mathrm{Sr}$ and ${ }^{137} \mathrm{Cs}$ in Whitefish

individual would incur a 50-year whole body dose commitment of 0.4 mrem and $0.3 \mathrm{mrem}$, respectively. The 50 -year respective dose commitment to the bone would be $10.3 \mathrm{mrem}$ and $0.2 \mathrm{mrem}$.

DEER

Each year a few deer are collected on the Hanford Site to assess the radionuclide concentrations in edible muscle tissue. The deer are generally "road kills". Table 7 shows the maximum, minimum, and average concentrations of ${ }^{40} \mathrm{~K}$ and ${ }^{137} \mathrm{Cs}$ observed during each of the years 1971 through 1975. Deer were also analyzed for Strontium-90. Except for one positive result $(0.008 \pm 0.005)$ during $1974,{ }^{90} \mathrm{Sr}$ was not detectible.

Figure 11 is a log-normal plot of the $40 \mathrm{~K}$ and ${ }^{137} \mathrm{Cs}$ data. Naturallyoccurring ${ }^{40} \mathrm{~K}$ was observed at a similar concentration for all of the deer samples and from the plotted data a median concentration of about $2.5 \mathrm{pCi} / \mathrm{g}$ would be expected. Only 5 of the 14 deer samples showed positive ${ }^{137} \mathrm{Cs}$ results. Aithough the observed ${ }^{137} \mathrm{Cs}$ concentrations are similar to the levels observed in beef (see Figure 5) which were attributed to fallout, it is 
TABLE 7. Radiochemical Analyses of Deer Muscle Samples

Units in $\mathrm{pCi} / \mathrm{g}$ (Wet Weight)

\begin{tabular}{|c|c|c|c|c|c|c|c|}
\hline \multirow[b]{2}{*}{ Year } & \multirow{2}{*}{$\begin{array}{l}\text { No. of } \\
\text { Samples }\end{array}$} & \multicolumn{3}{|c|}{$40 \mathrm{~K}$} & \multicolumn{3}{|c|}{$137 \mathrm{Cs}$} \\
\hline & & $\overline{\operatorname{Max}}$ & Min & $\overline{A v g}^{(a)}$ & $\overline{\mathrm{Max}}$ & Min & $\underline{\overline{A v g}}$ \\
\hline 971 & 2 & 2.9 & 2.9 & 2.9 & * & $\star$ & $<0.1$ \\
\hline 372 & 3 & 2.7 & 2.5 & 2.6 & 0.2 & * & $<0.1$ \\
\hline 1973 & 2 & 2.4 & 2.3 & 2.3 & 0.5 & * & $<0.3$ \\
\hline 74 & 3 & 2.3 & 2.2 & 2.2 & 1.8 & * & $<1.0$ \\
\hline 75 & 4 & 2.8 & * & $<2.3$ & 0.2 & * & $<0.1$ \\
\hline
\end{tabular}

kess than detectible. Detection levels are approximately: ${ }^{40} \mathrm{~K}$, $2 \mathrm{pCi} / \mathrm{g}$ and ${ }^{137} \mathrm{Cs}, 0.1 \mathrm{pCi} / \mathrm{g}$.

(a) Averages for data containing less-than values was calculated by assuming al1 less-than values are equal to the detection level and showing the average as a less-than number.

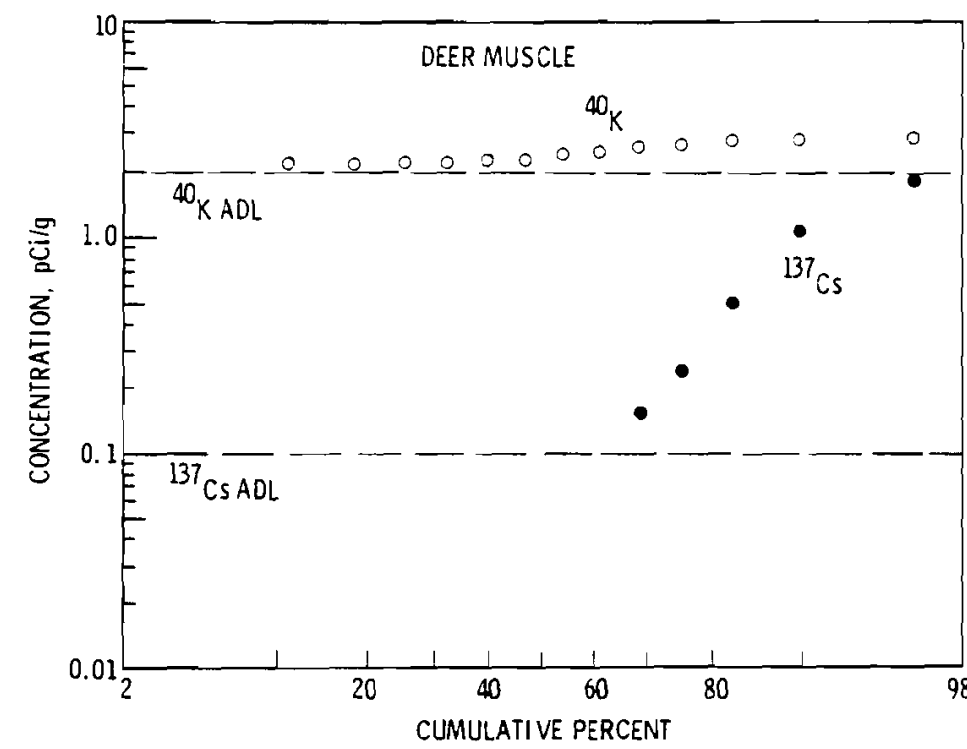

FIGURE 11. Levels of ${ }^{40} \mathrm{~K}$ and ${ }^{137} \mathrm{Cs}$ Shown in Deer Muscle Samples Collected Over the Period, 1971 Through 1975 
possible that Hanford operations have contributed to the observed levels. Assuming an individual were to consume $50 \mathrm{~kg}$ of deer meat which contained the maximum concentration observed $(1.8 \mathrm{pCi} / \ell)$ he would incur a 50 -year whole body dose commitment of about $5 \mathrm{mrem}$.

\section{WILLAPA BAY OYSTERS}

For many years, oysters have been collected from Willapa Bay along the coast of Washington to assess the significance of Hanford-originated radionuclides (primarily ${ }^{65} \mathrm{Zn}$ ) accumulated by the oysters. Table 8 summarizes the maximum, minimum, and average concentrations of $40 \mathrm{~K},{ }^{6} 5 \mathrm{Zn}$, and ${ }^{137} \mathrm{Cs}$ observed during each of the years 1971 through 1975. Naturally-occurring ${ }^{40} \mathrm{~K}$ was observed in all samples. For ${ }^{137} \mathrm{Cs}$, only 8 of the 35 oyster samples analyzed were greater than the approximate analytical detection level of $0.04 \mathrm{pCi} / \mathrm{g}$. These results, with a maximum of $0.06 \mathrm{pCi} / \mathrm{g}$, were only slightly greater than the detection limit and are attributed to either the statistical variability of low level counting or to the presence of $137 \mathrm{Cs}$ activity from fallout.

Zinc- 65 concentrations observed have shown a significant decline from 1971 to 1975 as shown by the average concentrations in Table 8. Figure 12 is a sequential plot of the ${ }^{40} \mathrm{~K}$ and ${ }^{65} \mathrm{Zn}$ results from 1971 through 1975. The decline in $65 \mathrm{Zn}$ activity is quite evident following shutdown of the last once-through cooling production reactor in January 1971. During the 5-year period, an approximate 100-fold decrease in $65 \mathrm{Zn}$ concentrations was observed. All analyses for ${ }^{65} \mathrm{Zn}$ during 1975 were below the detection 1 imit. The average concentration of $40 \mathrm{~K}$ observed during the 5 years is about $2 \mathrm{pCi} / \mathrm{g}$.

Fifty-year interna? dose commitment calculations were made using dose factors of 7 mrem for total body and 4.8 mrem for bone per $\mu \mathrm{Ci}$ of $65 \mathrm{Zn} \mathrm{ac-}$ tivity ingested. During 1971 with an average ${ }^{65} \mathrm{Zn}$ concentration of $4.6 \mathrm{pCi} / \mathrm{g}$, a person ingesting $9 \mathrm{~kg}$ * of oyster meat would have incurred a

\footnotetext{
*Consumption value obtained from ERDA 77-24 for the maximum individual dosage. (Reference \#2)
} 
TABLE 8. Radionuclides Observed in Willapa Oysters

Concentration, $\mathrm{pCi} / \mathrm{g}$ (Wet Weight)

\begin{tabular}{|c|c|c|c|c|c|c|c|}
\hline \multirow[b]{2}{*}{ Year } & \multirow{2}{*}{$\begin{array}{l}\text { No. of } \\
\text { Samples }\end{array}$} & \multicolumn{3}{|c|}{$40 \mathrm{~K}$} & \multicolumn{3}{|c|}{$65 \mathrm{Zn}$} \\
\hline & & Max. & Min. & Avg. $(b)$ & Max. & Min. & Avg. \\
\hline 1971 & 12 & 2.6 & 0.9 & 1.8 & 7.1 & 2.4 & 4.6 \\
\hline 1972 & 9 & 2.1 & 1.3 & 1.7 & 2.5 & 0.9 & 1.7 \\
\hline 1973 & 10 & 2.1 & 1.4 & 1.7 & 0.9 & 0.2 & 0.6 \\
\hline 1974 & 1 & 1.6 & 1.6 & 1.6 & 0.1 & 0.1 & 0.1 \\
\hline $1975^{(a)}$ & 3 & 1.7 & 1.7 & 1.7 & * & * & * \\
\hline
\end{tabular}

\begin{tabular}{|c|c|c|c|c|}
\hline \multirow[b]{2}{*}{ Year } & \multirow{2}{*}{$\begin{array}{l}\text { No. of } \\
\text { Samples }\end{array}$} & \multicolumn{3}{|c|}{${ }^{137} \mathrm{Cs}$} \\
\hline & & Max. & Min. & Avg. \\
\hline 1971 & 12 & 0.06 & * & $0.03-0.05$ \\
\hline 1972 & 9 & 0.05 & * & $0.01-0.04$ \\
\hline 1973 & 16 & * & * & * \\
\hline 1974 & 1 & * & * & * \\
\hline 1975 & 3 & * & * & * \\
\hline
\end{tabular}

\footnotetext{
“Less-than-detectible. Approximate detection levels are $0.08 \mathrm{pCi} / \mathrm{g}$ for ${ }^{65} \mathrm{Zn}$ and 0.04 for ${ }^{137} \mathrm{Cs}$.

(a) $40 \mathrm{~K}$ results for only one of the three samples analyzed was reported.

(b) Range of arithmetic average shown by assuming all lessthan results are alternatively equal to zero and then equal to the detection level.
} 


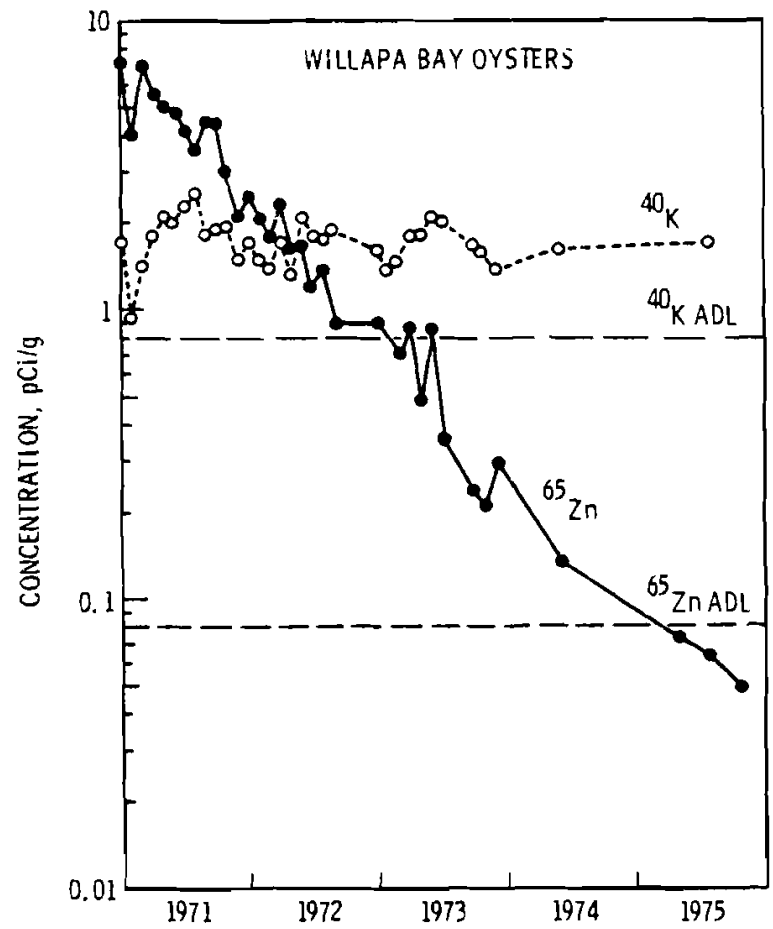

FIGURE 12. Plot of $40 \mathrm{~K}$ and $65 \mathrm{Zn}$ Concentrations in Willapa Bay Oysters

dose commitment to the total body and bone of $0.3 \mathrm{mrem}$ and $0.2 \mathrm{mrem}$, respectively. During 1975, the $65 \mathrm{Zn}$ concentration is about a 100-fold less, implying dose commitments much. less than $0.01 \mathrm{mrem}$.

The above dose estimates may be compared to the approximate $100 \mathrm{mrem} / \mathrm{yr}$ received from natural background radiation (a dose accumulation over 50 years of $5000 \mathrm{mrem})$. Naturally-occurring $40 \mathrm{~K}$ contributes, internally, a whole body dose of about $20 \mathrm{mrem} /$ year and is included in the $100 \mathrm{mrem} /$ year natural background dose. 


\section{ACKNOWLEDGMENTS}

The efforts of several persons have gone into production of this report which is part of the ERDA-sponsored Environmental Surveillance Program at Hanford. Extensive environmental data have been acquired during the program's existence. The laboratories of U. S. Testing Company performed the analyses. Sally Leete, under sponsorship of the Northwest Colleges and Universities for Science Program (NORCUS), analyzed much of the data in the report. Shellie Canada typed it. Clarice Hagen edited the report and arranged for publication. 


\section{REFERENCES}

1. J. J. Fix and P. J. Blumer Radiochemical Analyses of Game Birds Collected from the Hanford Environs 1971-1975. BNWL-2089, Battelle, Pacific Northwest Laboratories, Richland, WA 99352, July 1977.

2. J. P. Corley, et al., A Guide for Environmental Radiological Surveillance at ERDA Installations, ERDA 77-24, Energy Research and Development Administration, Division of Safety, Standards, and Compliance, Washington, DC 20545, March 1977. 


\section{DISTRIBUTION}

No. of

Copies

OFFSITE

1 A. A. Churm, Director

Patent Division

ERDA Chicago Operations

Office

9800 South Cass Avenue

Argonne, IL 60439

27 DOE Technical Information Center

2 R. Woodruff

Washington Public Power Supply System

P. 0. Box 968

3000 George Washington Way

Richland, WA 99352

\section{ONSITE}

10 DOE Richland Operations Office, Environmental Affairs

0. J. Elgert

D. R. Elle (6)

H. E. Ransom

F. R. Standerfer

M. W. Tiernan

\section{Rockwell International}

W. F. Heine

G. C. Owens

J. V. Panesko

Rockwell Files
No. of

Copies

1 Hanford Envirormental Health Foundation

B. D. Reinert

2 United Nuclear Industries, Inc.

T. E. Dabrowski

UNI Files

2 Westinghouse Hanford Company

\section{R. Belanger}

G. D. Carpenter

63 Battelle-Northwest

P. J. Blumer

P. E. Bramson

J. P. Corley

J. J. Fix (20)

R. F. Foster

J. J. Fuquay

H. V. Larson

S. C. Leete (20)

M. L. Miller (6)

J. M. Selby

J. K. Soldat

G. A. Stoetzel

C. M. Unruh

D. A. Waite

Technical Information (5)

Technical Publications 